\title{
Phytoprotection
}

phytoprotection

\section{Encre des chênes rouges : pouvoir de dissémination du Phytophthora ramorum en milieu naturel}

\section{Danny Rioux}

Volume 86, numéro 1, avril 2005

URI : https://id.erudit.org/iderudit/011706ar

DOI : https://doi.org/10.7202/011706ar

Aller au sommaire du numéro

Éditeur(s)

Société de protection des plantes du Québec (SPPQ)

ISSN

0031-9511 (imprimé)

1710-1603 (numérique)

Découvrir la revue

Citer cet article

Rioux, D. (2005). Encre des chênes rouges : pouvoir de dissémination du Phytophthora ramorum en milieu naturel. Phytoprotection, 86(1), 3-3.

https://doi.org/10.7202/011706ar d'utilisation que vous pouvez consulter en ligne.

https://apropos.erudit.org/fr/usagers/politique-dutilisation/ 


\section{Encre des chênes rouges: pouvoir de dissémination du Phytophthora ramorum en milieu naturel}

La maladie de l'encre des chênes rouges ne s'est pas encore établie au Canada bien que l'agent causal, Phytophthora ramorum, ait été détecté dans de nombreuses pépinières de la Colombie-Britannique à la suite d'introductions en 2003 et 2004. Cette maladie est une menace sérieuse puisque I'on a rapporté aux États-Unis et en Europe qu'environ 75 espèces d'arbres et de plantes horticoles pouvaient être infectées par le $P$. ramorum. Elle est présente en milieu naturel en Amérique du Nord dans 14 comtés en Californie et dans un comté de l'Oregon. On connaît mal le potentiel de propagation de cet agent pathogène. L'étude mentionnée ci-dessous confirme que les chênes infectés sont de pauvres producteurs de spores même si ces arbres en meurent généralement alors que le laurier (Umbellularia californica), survivant toujours à l'infection, s'avère le principal hôte sur lequel $P$. ramorum sporule en milieu naturel en Californie. En laboratoire, 80 à $100 \%$ des feuilles de laurier produisent des chlamydospores et des sporanges et le nombre de zoospores produit par feuille peut atteindre 5 200. Lors de pluies accompagnées par de forts vents, les auteurs rapportent que les propagules peuvent être transportées jusqu'à au moins $15 \mathrm{~m}$ de la source la plus proche de matériel infecté. Dans les cours d'eau, $P$. ramorum a été détecté jusqu'à un kilomètre des sites contaminés, un fait peu surprenant puisque les auteurs ont montré que les zoospores peuvent survivre jusqu'à 6 mois dans de l'eau distillée. Cette étude révèle aussi que $P$. ramorum peut infecter des feuilles de laurier placées sur du sol infesté et que ces feuilles peuvent à leur tour transmettre la maladie à des semis lors d'éclaboussures causées par la pluie. Ces résultats couplés au fait que jusqu'à $50 \%$ des randonneurs testés pouvaient transporter du sol contaminé sur leurs chaussures montrent bien que cet agent pathogène possède plus d'une corde à son arc pour se propager efficacement en nature.

\section{Sudden oak death: propagation potential of Phytophthora ramorum in nature}

\begin{abstract}
Sudden oak death is not yet established in Canada although the causal agent, Phytophthora ramorum, has been detected in several nurseries in British Columbia following introductions in 2003 and 2004. This disease represents a serious threat as it has been reported in the United States and Europe that $P$. ramorum can infect about 75 tree species and horticultural plants. The disease is found in nature in North America in 14 California counties and one county in Oregon. The propagation potential of this pathogen is poorly understood. The study mentioned below confirms that infected oaks are not good hosts for the production of spores even though they are often killed by the pathogen whereas bay laurel (Umbellularia californica), which always survives to the disease, is the most important source of inoculum in California. Under laboratory conditions, 80 to $100 \%$ of bay laurel leaves produce chlamydospores and sporangia, and as many as 5200 zoospores can be generated on a single infected leaf. This study reports that during storm events propagules can move as far as $15 \mathrm{~m}$ away from the inoculum source. In streamwater, $P$. ramorum is detected $1 \mathrm{~km}$ away from the nearest infested sites, which is not that surprising considering that these authors have also shown that zoospores can survive 6 months in distilled water. This study also reveals that $P$. ramorum can infect bay laurel leaves placed on infested soil and that the pathogen can move from these leaves to nearby seedlings following rain splashes. These results, coupled with the fact that the pathogen could be isolated from the shoes of as many as $50 \%$ of the hikers tested, show that $P$. ramorum can use many strategies to increase its dissemination in nature.
\end{abstract}

Davidson, J.M., A.C. Wickland, H.A. Patterson, K.R. Falk, and D.M. Rizzo. 2005. Transmission of Phytophthora ramorum in mixed-evergreen forest in California. Phytopathology 95 : 587-596.

Soumis par Danny Rioux, Service canadien des forêts, Sainte-Foy (Québec) 